Збірник наукових прачь Державного науково-дослідного інституту випробувань і сертифікачї̈ озброєння та військової техніки. 2019. Вип. № 2

Брайко В.В., Сподін О.І., Скляр В.Г. Товариство з обмеженою відповідальністю “Наукововиробнича фірма "Адрон”

Камак Ю.О., Нікітченко В.І. Державний науково-дослідний інститут випробувань $i$ сертифікації озброєння та військової техніки

\title{
ОСОБЛИВОСТІ ФУНКЦІОНУВАННЯ ТА РОЗРОБКИ ТЕРМОБАРИЧНИХ БОСПРИПАСІВ
}

У статті акцентовано увагу на особливості функціонування термобаричних вибухових речовин. Показано основні переваги та недоліки термобаричних вибухових речовин різних поколінь. Проведено оцінку стадій вибух термобаричних зарядів. Проаналізовано характер навантаження при оціниі уражаючої діі термобаричних вибухових речовин. Визначено, щзо характер навантаження пов'язаний зі співвідношенням тривалості фази стискання в ударній хвилі та періоду власних коливань об'єкта.

Ключові слова: уражаюча дія, оцінка функціонування, термобаричні вибухові речовини.

\section{Постановка проблеми}

Застосування будь-яких боєприпасів при виконанні поставлених бойових завдань повністю визначається показником їх бойової ефективності, в якості якого може виступати ймовірність виконання бойового завдання або рівень нанесеного збитку.

Однією 3 основних характеристик будь-яких боєприпасів, що безпосередньо впливають на зазначені показники, є тип бойової частини і тип вибухової речовини, яка застосовується у бойовій частині. Характеристики бойової частини і вибухових речовин $\epsilon$ взаємозалежними величинами.

За характеристиками уражаючої дії бойові частини класифікуються як кінетичні, запальні, осколкові, фугасні, кумулятивні, термобаричні, спеціального призначення, а також їх комбінації (наприклад, осколково-фугасні і т.д.) [1].

Відповідно, залежно від виду уражаючої дії бойова частина споряджається певною вибуховою речовиною, що дає максимальний ефект на визначені типові цілі. 3 метою оцінки (уточнення) уражаючої дії боєприпасів 3 термобаричними вибуховими речовинами та ефективного їх застосування доцільно розглянути питання особливостей функціонування та розробки термобаричних боєприпасів.

\section{Аналіз останніх досліджень і публікацій та виклад основного матеріалу}

Вибухові речовини - це хімічні сполуки або суміші речовин, здатні до швидкої хімічної реакції, що супроводжується виділенням великої кількості тепла та утворенням газів. Ця реакція, яка виникла в результаті нагрівання, удару, тертя, вибуху іншої вибухової речовини або зовнішнього впливу, поширюється по заряду за рахунок передачі енергії від шару до шару за допомогою процесів тепло- і масового переносу (горіння) чи ударної хвилі (детонаціі).

Швидкість горіння різних вибухових речовин коливається від десятих мм/с до десятків і сотень м/с, швидкість детонації може перевищувати $9000 \mathrm{~m} / \mathrm{c}$. Вибуховими речовинами можуть бути конденсовані (тверді й рідкі) речовини, гази, а також суспензії часток твердих або рідких речовин у газах [2].

Реакція детонації відбувається так швидко, що газоподібні продукти з температурою у кілька тисяч градусів виявляються стислими в обсязі, близькому до вихідного обсягу заряду,

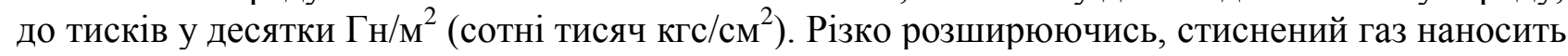
по навколишньому середовищу удар величезної сили. В результаті чого відбувається процес вибуху. Матеріали, що перебувають поблизу від заряду, зазнають подрібнення та значної пластичної деформації (місцева або бризантна дія вибуху), на деякій відстані від заряду 
руйнування менш інтенсивні, але зона, у якій вони відбуваються, набагато збільшується (загальна або фугасна дія вибуху). Тиск Р, що розвивається при детонації, та бризантність вибухових речовин залежать від щільності заряду й швидкості детонації. Фугасність вибухових речовин визначається теплотою, а також обсягом газоподібних продуктів вибуху. Звичайно, фугасність виражають у відносних одиницях, використовуючи в якості стандартних вибухових речовин тротил (тротиловий еквівалент), гримучу суміш чи амоніт № 6, або в одиницях енергії.

Існують різні підходи до класифікації існуючих вибухових речовин та тих, що розробляються, але загальноприйнятою є класифікація за областю застосування. При такому підході вибухові речовини ділять на три групи: ініціюючі, бризантні та метальні $[1,2]$.

Основну роль за критерієм уражаючої дії виконують бризантні вибухові речовини, серед яких є і боєприпаси об'ємного вибуху.

Об’ємно-детонуючі боєприпаси (ОДБ) це боєприпаси, що розпилюють горючу речовину, створюючи аерозольну хмару та підривають і1і. Боєприпаси об'ємного вибуху великих калібрів за потужністю вибуху можуть бути порівняні з малими тактичними ядерними боєприпасами, але в них відсутній радіаційна уражаюча дія .

Принцип дії ОДБ заснований на детонації хмари горючого аерозолю. Завдяки, більшим розмірам хмари (на порядок більшою, ніж розміри зарядів 3 конденсованою вибуховою речовиною), ударна хвиля зберігає уражаючу дію на великій відстані [3]. Вибух відбувається у дві стадії:

- за командою підривача, як правило, безконтактного, підривається невеликий заряд звичайної вибухової речовини (його завдання - рівномірно розподілити горючу речовину за обсягом хмари);

- з невеликою затримкою підривається другий заряд (або кілька зарядів), що викликає детонацію аерозолю.

У якості пального в ОДБ використовують:

- окис етилену;

- окис пропілену; піперилен;

- пропіл-ацетилен та діметил-ацетилен;

- бутил-нітрат та пропіл-нітрат.

Однак бойове застосування таких боєприпасів показало ряд проблемних питань [4]:

- низька надійність через складну схему роботи та великий процент випадків неспрацьовування виробів або позаштатних режимів роботи (наприклад, вигоряння хмари замість детонації);

- вплив погодних умов на ефективність їх застосування (вітер, сніг, дощ, туман і т.д.);

- наявність мінімальної критичної маси термобаричних вибухових речовин (не менш $20 \ldots 30$ кг);

- мінливість тротилового коефіцієнта, виявлення критичних залежностей відстаней між типовою ціллю і вибуховим пристроєм та швидкості вибухового перетворення.

- обмеження по швидкості та куту підльоту до типової цілі (обов'язкове використання парашутних систем).

На сьогодні, розробка ОДБ спрямована на розробку технологій створення більш рівномірної хмари повітряно-паливної суміші та більш симетричного іï підриву - умов, за якими досягається максимальний ефект.

Окремою галуззю розвитку ОДБ є термобаричні вибухові речовини. Термобаричні заряди складаються 3 центрального розривного заряду (ЦРЗ), який виконаний зі звичайної вибухової речовини з високою швидкістю детонації, навколо якої перебуває термобарична суміш, що представляє собою конденсовані вибухові речовини 3 високим вмістом металевого пального [2,7].

Вибух термобаричних зарядів складається з трьох стадій:

1. Підрив ЦРЗ, що дає початкову детонаційну хвилю (тривалість - мікросекунди).

2. Детонаційна хвиля від ЦРЗ ініціює детонацію термобаричних сумішей, що детонує 
3 меншою швидкістю (анаеробна стадія, тривалість - сотні мікросекунд).

3. Розширення та горіння продуктів вибуху за рахунок кисню повітря за фронтом ударної хвилі. При цьому ударна хвиля сприяє перемішуванню та згорянню продуктів детонації за рахунок навколишнього повітря (аеробна стадія, тривалість - мілісекунди і більше).

На відміну від об'ємно-детонуючих зарядів термобаричні боєприпаси не обмежені критичною масою (не менше 20-30 кг), менше якої об'ємно-детонуючі боєприпаси не ефективні. Це дозволяє озброювати термобаричними боєприпасами відносно невеликі підрозділи, до окремих бійців. Перевагою термобаричних боєприпасів у порівнянні 3 об'ємно-детонуючими боєприпасами $є$ відсутність впливу на них атмосферних явищ (наприклад, дії вітру) та для організації вибуху не потребується часу для формування хмари. Крім того, ударна хвиля від вибуху термобаричних зарядів здатна затікати в укриття. Однак, ефективність термобаричних боєприпасів на відкритій місцевості порівняно невисока: лише в закритих i напівзакритих просторах вони показують підвищену ефективність завдяки інтенсивному догорянню часток металу.

На практиці розроблені реактивний піхотний вогнемет (РПО) “Джміль” і важка вогнеметна система (ТОС) “Буратіно” [5,6].

У реактивному піхотному вогнеметі РПО-А “Джміль” використовується той же принцип - ЦРЗ і рідка термобарична суміш на основі летючих нітроефірів 3 40-50\% вмістом порошку магнію [3]. Маса ЦРЗ (ТГ 40/60) становить всього 10\% суміші.

Існують, також, тверді термобаричні суміші, наприклад А-3 (гексоген-віск-алюміній 3 дольовим відношення компонентів 65/5/30), що не мають істотних переваг перед рідкими, крім зручності у використанні.

На сьогодні розроблені термобаричні заряди другого покоління, що представляють собою тверді термобаричні суміші до складу яких входять хімічні сполуки, які збільшують тривалість третьої стадії вибуху термобаричних вибухових речовин до сотень мілісекунд $\mathrm{i}$ практично не залежать від кисню повітря [2,7]. Це дозволяє знизити відсоток вибухових речовин у сумішах. При цьому ефективність термобаричних вибухових речовин зростає.

Перевагами термобаричних вибухових речовин другого покоління є:

- збільшений час тривалості вибуху;

- збільшений час високотемпературного впливу на ціль;

- можливість застосування під водою;

- затікання вогненної хмари в укриття;

- збереження ефективності в умовах щільної рослинності (ліс, джунглі);

- незалежність від метеорологічних умов;

- тривалий час зберігання в порівнянні з рідкими термобаричними сумішами;

- зручність у використанні;

- простота та безпека виробництва;

- відсутність гігроскопічності.

Термобаричні вибухові речовини другого покоління також мають і недоліки:

- достатньо великий діаметр заряду термобаричних вибухових речовин, що обумовлене критичним діаметром вибухових речовин розривного заряду.

- складність спорядження (заливання) боєприпасів зі складною формою корпусу.

Перспективними розробками термобаричних вибухових речовин $\epsilon$ розробки вибухових речовин третього покоління, які у своєму складі не містять розривного заряду. Заряди термобаричних вибухових речовин третього покоління (залиті та запресовані) дозволяють споряджати боєприпаси малого калібру (від 30 мм). Також можна відзначити, що при певних рецептурах термобаричних вибухових речовин третього покоління, при їх підриві, з корпусу таких боєприпасів можна сформувати високошвидкісне поле осколків, яке можна використовувати в якості додаткового уражаючого фактора.

Перевагами термобаричних вибухових речовин третього покоління $є$ :

- збільшений час тривалості вибуху; 
- збільшений час високотемпературного впливу на ціль;

- можливість формування зарядів-вкладишів (пресування);

- можливість спорядження боєприпасів малих калібрів;

- низька чутливість до перевантажень. Це дуже важливо для боєприпасів зі значними стартовими перевантаженнями (артилерійські постріли);

- можливість спорядження боєприпасів з корпусом складної форми (заливання);

- простота та безпечність виробництва;

- відсутність гігроскопічності;

- можливість застосування під водою;

- можливість застосування в боєприпасах осколкової дії 3 незначною втратою термобаричного ефекту;

- досить великий строк зберігання.

У цьому випадку вибір типу термобаричних вибухових речовин визначається умовами бойового застосування, масою та габаритами бойових частин.

Результати уражаючої дії боєприпасів з термобаричними вибуховими речовинами на різні цілі необхідно оцінювати виходячи із двох факторів вибуху: тиску та температури.

Фактор тиску оцінюється надлишковим тиском $\Delta \mathrm{P}_{\mathrm{m}}$ i питомим імпульсом фази стискання при надлишковому тиску $\left(i_{+}\right)$в ударній хвилі.

У випадку наявності зони стискання у фронті ударної хвилі характеристики ураження цілей носять квазістатичний характер (миттєва дія постійного тиску), а деформація цілей визначається максимальним надлишковим тиском. При короткій тривалості ударної хвилі реакція цілей на навантаження визначається питомим імпульсом фази стискання (імпульсне навантаження).

Вибір характеру навантаження при оцінці уражаючої дії термобаричних вибухових речовин пов'язаний зі співвідношенням тривалості фази стискання в ударній хвилі $\tau$ та періоду власних коливань об'єкта Т [2,7].

Якщо тривалість фази стискання $\tau \leq 0,25 \mathrm{~T}$, то навантаження можна вважати імпульсним, а умова руйнування цілі є критерій, який визначається питомим імпульсом:

$$
i_{+} \geq i_{+}^{\mathrm{Kp}} .
$$

При $\tau \leq 10$ Т навантаження стає квазістаціонарним і критерій руйнування виражають через надлишковий тиск:

$$
\Delta P_{m} \geq \Delta P_{m}^{\mathrm{\kappa p}} .
$$

Зазначені співвідношення називають приватними критеріями ураження цілі в результаті фугасної дії ударної хвилі боєприпасів 3 термобаричними вибуховими речовинами.

При $0,25 \mathrm{~T}<\tau<10 \mathrm{~T}$ на об'єкт впливає як максимальний надлишковий тиск, так i питомий імпульс в ударній хвилі. У цьому випадку можна скористатися узагальненим критерієм:

$$
\left(\Delta P_{m}-\Delta P_{m}^{\mathrm{\kappa p}}\right)\left(i_{+}-i_{m}^{\mathrm{\kappa p}}\right)=K,
$$

де $K$ - константа, значення якої визначаються експериментально для кожного об'єкта, залежно від виду ураження.

Фактор температури оцінюється розподілом температури від точки підриву до межі області та часу існування області. Дані показники впливають на рівень ураження різних цілей, в тому числі живої сили.

\section{Висновки}

1. Класифікувати вибухові речовини як термобаричні доцільно при оцінці фізичного процесу вибуху з специфічними ознаками, такими як підвищеними параметрами термічного впливу та позитивної фази надлишкового тиску у фронті ударної хвилі. Так, основними факторами уражаючої дії боєприпасів з термобаричними вибуховими речовинами типових цілей є надлишковий тиск і питомий імпульс фази стискання в ударній хвилі та температура.

2. Перспективними розробками термобаричних вибухових речовин $\epsilon$ розробки 
вибухових речовин третього покоління, які у своєму складі не містять розривного заряду. Заряди термобаричних вибухових речовин третього покоління (залиті та запресовані) дозволяють споряджати боєприпаси малого калібру (від 30 мм). При певних рецептурах термобаричних вибухових речовин третього покоління, при їх підриві, з корпусу таких боєприпасів можна сформувати високошвидкісне поле осколків, яке можна використовувати в якості додаткового уражаючого фактора.

3. Розробка боєприпасів 3 термобаричними вибуховими речовинами вимагає попередніх теоретичних та експериментальних розрахунків. При проведенні розрахунків необхідно враховувати конкретні завдання щодо ураження цілей боєприпасами 3 термобаричними бойовими частинами.

\section{СПИСОК ЛІТЕРАТУРИ}

1. Пиросправка. Справочник по взрывчатым веществам, порохам и пиротехническим составам. - М.:, 2012 - Издание 6. - 310 с.

2. Бабкин А.В. Средства поражения и боеприпасы / А.В. Бабкин, В.А. Велданов, В.Ф. Грязнов и д.р. -М.: МГТУ им. Н.Э. Баумана, 2008. - 984 с.

3. Аркашев А. Зажигательное и огнеметное оружие / А. Аркашев. - М.: Яуза, 2009. $-704 \mathrm{c}$.

4. Ларіонов В.В. Аналіз розвитку та основні тенденції застосування термобаричних боєприпасів. / В.В. Ларіонов, К.М. Хом'як, Р.В. Казмірчук, О.С. Івахів, М.О. Платонов, О.М. Стаднічук // Збірник наукових праць. Національна академія Сухопутних військ імені гетьмана Петра Сагайдачного. - Львів:, 2016. - Випуск №15. - С 28-31.

5. Jeremy Bender There Are The Weapons That Russian Is Pouring Into Eastern Ukraine. [Електронний ресурс] - Режим доступу: http://ur.busanessins.com/weapons-russian-is-pouringinto-east-ukraine. - дата доступу: - 2015-01-22.

6. Россия (СССР) в локальных войнах и вооруженных конфликтах второй половины ХХ века; Под. ред. В.А. Золотарева. - М.: Кучково поле. Полиграф-ресурсы, 2000 - 576 с.

7. Никулин Е.Н. Средства ближнего боя. Ручные гранатометы / Е.Н.Никулин, Е.Н. Руссков, И. А. Семенов. - С.-П., 2007, - 139 с.

\section{Брайко Володимир Вікторович}

провідний конструктор товариства 3 обмеженою відповідальністю "Наукововиробнича фірма “Адрон”, Київ, Україна https://orcid.org/0000-0002-8273-8919 e-mail:bvv@adron.ua

Сподін Олександр Іванович провідний конструктор товариства 3 обмеженою відповідальністю "Наукововиробнича фірма “Адрон”, Київ, Україна https://orcid.org/0000-0002-9843-1145 e-mail: alyshin@adron.ua

\section{Скляр Василь Григорович}

провідний конструктор товариства 3 обмеженою відповідальністю "Наукововиробнича фірма “Адрон”, Київ, Україна https://orcid.org/0000-0001-8253-7415 e-mail: vasia.skliar@gmail.com

\section{Braiko Vladimir}

Lead Designer of Adron Research and Development Co. Ltd.

Kyiv, Ukraine

https://orcid.org/0000-0002-8273-8919

e-mail:bvv@adron.ua

\section{Spodin Alexander}

Lead Designer of Adron Research and Development Co. Ltd.

Kyiv, Ukraine https://orcid.org/0000-0002-9843-1145 e-mail: alyshin@adron.ua

\section{Skliar Vasyl}

Lead Designer of Adron Research and Development Co. Ltd.

Kyiv, Ukraine https://orcid.org/0000-0001-8253-7415

e-mail: vasia.skliar@gmail.com 


\section{Камак Юрій Олександрович}

начальник науково-дослідного управління Державного науково-дослідного інституту випробувань і сертифікації озброєння та військової техніки, Чернігів, Україна https://orcid.org/0000-0003-1953-411X e-mail:dnvc@meta.ua

\section{Нікітченко Віктор Іванович}

кандидат технічних наук, начальник науково-дослідного відділу Державного науково-дослідного інституту випробувань i сертифікації озброєння та військової техніки, Чернігів, Україна https://orcid.org/0000-0001-8973-8711 e-mail:nazar200914@gmail.com

\section{Kamak Yuri}

Chief of Division of State Scientific Research Institute of Armament and Military Equipment Testing and Certification, Chernihiv, Ukraine https://orcid.org/0000-0003-1953-411X e-mail:dnvc@meta.ua

\section{Nikitcnenko Viktor}

Candidate of Technical Sciences, Chief of Section of State Scientific Research Institute of Armament and Military Equipment Testing and Certification, Chernihiv, Ukraine https://orcid.org/0000-0001-8973-8711 e-mail:nazar200914@gmail.com

\section{FEATURES OF FUNCTIONING AND DEVELOPMENTS OF THERMOBARIC AMMUNITIONS V. Brajko, A. Spodin, V. Skliar, Y. Kamak, V. Nikitcnenko}

One of the basic features of any ammunitions, which directly influence the noted characteristics, are: the type of war-head and the type of explosive which is used in a war-head. The characteristics of the war-head and explosives are interdependent parameters.

Brisant explosives play a basic role in the criterion of destructive effect. Among brisant explosives there are fuel-air explosives. The concept of action of fuel-air explosion ammunitions is based on detonation of cloud combustible to the aerosol. Due to the greater sizes of cloud (much more than charges with the condensed explosive), a shock wave keeps a destructive effect at long range.

Thermobaric explosives are a specific industry of development of fuel-air explosives. Thermobaric charges consist of central burster which is executed from ordinary explosives with high-rate of detonation, around which there is a thermobaric mixture $i$. e. condensed explosives with high content of metal fuel.

Advantage of thermobaric explosive ammunition in comparison with fuel-air explosive ammunition is absence of atmospheric phenomena effects on them (for example effect of wind). Moreover, for initiation of explosion the time is not rquired for forming a cloud.

In addition, a shock wave from the explosion of thermobaric charges is able to flow in shelter. However, effectiveness of thermobaric ammunitions in open terrain comparatively is not high: only in the closed and half-closed spaces they show the increased effectiveness due to the intensive ability of metal parts to finish burning in such closed area.

The results of destructive effect of ammunitions with thermobaric explosives on different targets are considered taking into account two factors of explosion: pressure and temperature. The factor of pressure is assessed by surplus pressure $\triangle P m$ and specific impulse of contraction phase at surplus pressure $(i+)$ in a shock wave. The factor of temperature is assessed by distribution of temperature from the point of explosion to the limit of the area and area existence time.

Perspective developments of thermobaric explosives are developments of explosives of the third generation, which in the composition do not contain a burster. The charges of thermobaric explosives of the third generation allow to equip ammunitions of small caliber.

Keywords: destructive effect, estimation of functioning, thermobaric explosives. 